\title{
The Use of Medicinal Clay from Silesia "Terra sigillata Silesiaca", Central Europe - A New Chance for Natural Medicine?
}

\author{
Krzysztof Spałek $^{1 *}$ and Izabela Spielvoge ${ }^{2}$ \\ ${ }^{1}$ Institute of Biology, University of Opole, Poland \\ ${ }^{2}$ Department of Physiotherapy, Institute of Physiotherapy, Opole University of Technology, Poland \\ *Corresponding author: Krzysztof Spałek, Institute of Biology, University of Opole, Poland
}

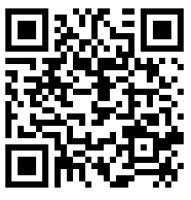

\section{ARTICLE INFO}

Received: 慧 August 02, 2019

Published: 彗 August 12, 2019

Citation: Krzysztof Spałek, Izabela Spielvogel. The Use of Medicinal Clay from Silesia "Terra sigillata Silesiaca", Central Europe - A New Chance for Natural Medicine?. Biomed J Sci \& Tech Res 20(3)-2019. BJSTR. MS.ID.003457.

Keywords: Peloids; Medicinal clays; Silesia; Balneotherapy; Medical treatment

\author{
ABSTRACT
}

Silesia is a region in Central Europe with beneficial conditions for the presence of clay, including those with potential therapeutic efficacies, due to its very diverse and mosaic geological landscape. The first use of clay deposits in medicine in Silesia, "terra sigillata Silesiaca", has been dated to $1550 \mathrm{AD}$, and the oldest written information related to this use has been dated to $1586 \mathrm{AD}$. Medicinal clay is formed by the accumulation of a mixture of minerals such as smectite, bentonite, montmorillonite, kaolinite, illite, and metahaloisite, with impurities of other minerals and fractions, resulting from the chemical weathering of rocks and the sedimentation of detritus.

The quantitative ratios of individual minerals are very diverse, similar to the diverse chemical composition, and mainly depend on the type of rocks from which the clay was weathered, the sedimentation conditions, and the processes that occur after sedimentation. Medicinal clays derived from basalt weathering have different properties to those derived from the weathering of granite, amphibolite, gneisse, or limestone. Although clays were used for medicinal purposes for millennia, they remained largely unexamined in terms of their mechanism of action and potential benefits in medicine. Recently, however, there has been an increased interest in the geochemical properties of these minerals with respect to antibacterial and anti-inflammatory action. Currently, in 2017-2018, two historic healing clay "terra sigillata Silesiaca" deposits have been confirmed in Silesia, which, after previous research, may be used in natural medicine.

\section{Introduction}

\section{Medicinal Clay in Ancient Times}

Due to its therapeutic properties, clay has been used in medicine worldwide since ancient times, which was even mentioned by Aristotle (384-322 B.C.) [1-3]. In traditional human medicine, clay has been used both externally and internally, for instance, as an aseptic, astringent, and absorbing agent. In the 1st century A.D., Pliny the Elder (23-79) described the therapeutic properties of clays from Lemnos, Eritrea, Samos, Chios, and Melos. The good name of therapeutic soils was established in the $2^{\text {nd }}$ century A.D. by the Greek physician, Galen (130-210), who in his ninth book entitled "De simplicium medicamentorum temperamentis ac facultatibus", described therapeutic soils used in traditional medicine [4]. Guided by his own experience and stories by others, he determined the indications for their use, mainly focusing on the actions of clay from Lemnos; "terra sigillata Lemnia". Lemnos clay was used to treat ulcers, diarrhea, snake bites, mad dogs, and other animals. The medieval doctor Avicenna (980-1037) mentioned clays from Lemnos and Samos in his works, as did the Muslim doctor and pharmacotherapies, Ibn al-Baitar (1197-1248).

At the end of the $15^{\text {th }}$ century, medicinal clays were mentioned in the famous work of "Gart der Gesundheit" from 1470, published in Mainz at the request of Bernhard von Breidenbach (1440-1497) 
[1]. In the 16th century, Paracelsus (1493-1541), a physician and surgeon, used the term "terra sigillata" for the first time to describe a clay from Malta; however, this term is now specifically used to describe clay from Lemnos. Bernard Palissy (1510-1589), a French potter, geologist, and natural historian, attempted to explain the action of "terra sigillata Lemnia" in his work entitled "Discours admirables" from 1580, concluding that this type of clay may also be present in other parts of the world, an assumption which was later proven correct [5]. He suggested that it may be present in Turkey, however a similar clay was found in the $16^{\text {th }}$ century in Central Europe, specifically in Silesia, being part of the Habsburg Empire at that time [6-9].

Caspar Schwenckfeld (1563-1609) was a spa doctor from Cieplice, Silesia, and a botanist, mineralogist, zoologist, and natural historian of the Karkonosze region, regarded as one of the outstanding Silesian scientists of the Renaissance, who also mentioned "terra sigillata Silesiaca" in his monograph "Stirpium \& Fossilium Silesiae Catalogus" [10]. The therapeutic use of clay (terra sigillata medicorum) by potters in human and pet animals was known until the $19^{\text {th }}$ century in places of different cultures or religions around the world [11-16]. At the end of the $19^{\text {th }}$ century, Sebastian Kneipp (1821-1897), a creator of prophylactics and treatments who practiced in Bavaria, described in the List of Intangible Cultural Heritage of Humanity of UNESCO in 2015 treatment with clay compresses for ulceration, slow-healing cuts or stab wounds, and insect bites [17].

\section{Medicinal Clay in Silesia: "Terra sigillata Silesiaca”}

Silesia is a region in Central Europe with beneficial conditions for the presence of clay, including those with potential therapeutic efficacies, due to its very diverse and mosaic geological landscape. The majority of this region contains Paleozoic, magmatic, volcanic, and metamorphic rocks, the weathering of which has resulted in the present kaolinic clays. Weathering in the warm climates of the Mesozoic and early Cenozoic eras was beneficial to these clays, which are present, among others, in the Strzegom and Złotoryja regions, where their therapeutic use has been documented. The northern part of Silesia was formed by the deposits of ForeSudetic Monocline, around which clays, silts, claystones, and mudstones of the Triassic (upper Triassic mainly) and Jura (lower Jura mainly) eras are found, which were deposited in the sea and limnic environments, in addition to being formed from decayed limestone (basal kaolinic clay). Triassic and Jura clays were used in therapeutics from at least the $17^{\text {th }}$ century and were known in Europe as the layers present within the Olesno and Płużnica regions [18].

The first use of clay deposits in medicine in Silesia, "terra sigillata Silesiaca", has been dated to $1550 \mathrm{AD}$, and the oldest written information related to this use has been dated to 1586 $\mathrm{AD}$ [20]. These deposits were described by their discoverer, the Renaissance physician and geologist Johann Schulz (1531-1604), also known as Johannes Scultetus Trimontanus or Johannes Montanus, in "Judieum de terra sigillata strigoviensis" published in Nuremberg. He was the son of a surgeon acting in Strzegom; he studied at the University of Bologna and graduated in 1557 to begin his career as a physician in Jelenia Góra [1]. His work described three types of Silesian medicinal clay "terra sigillata Silesiaca": clay from Strzegom "terra sigillata Strigoniensis" also called "Monits Acuti"; clay from Legnica "terra sigillata Lignicensis"; and clay from Złotoryja "terra sigillata Goltbergensis" (Figure 1). Thanks to his discovery, Montanus became famous and the personal doctor of Emperor Rudolph II

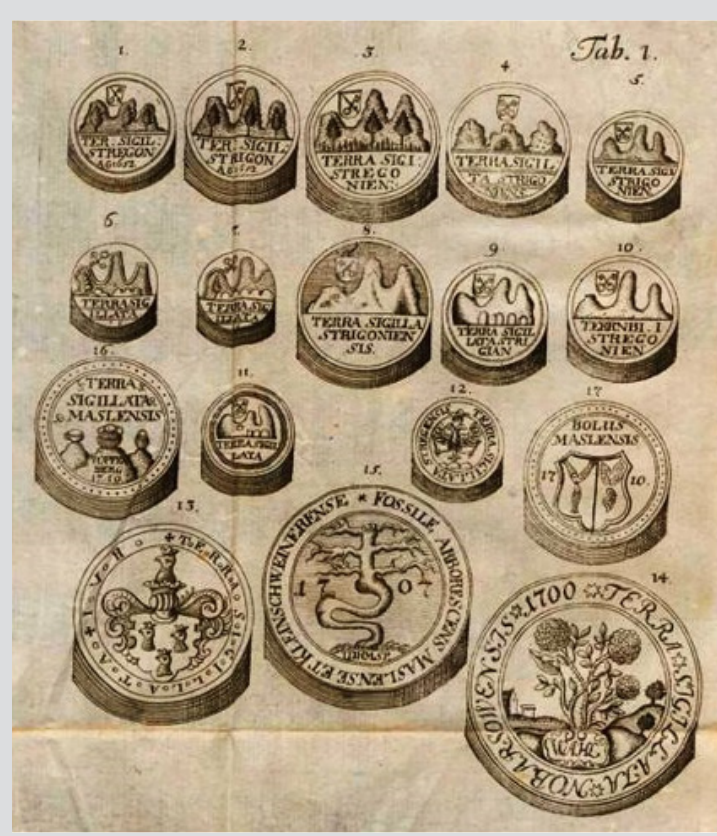

Figure 1: Patterns of the seal showing the tablets of medicinal clay "terra sigillata Silesiaca" [6].

Medicinal clay is formed by the accumulation of a mixture of minerals such as smectite, bentonite, montmorillonite, kaolinite, illite, and metahaloisite, with impurities of other minerals and fractions, resulting from the chemical weathering of rocks and the sedimentation of detritus. The quantitative ratios of individual minerals are very diverse, similar to the diverse chemical composition, and mainly depend on the type of rocks from which the clay was weathered, the sedimentation conditions, and the processes that occur after sedimentation. Medicinal clays derived from basalt weathering have different properties to those derived from the weathering of granite, amphibolite, gneisse, or limestone. In Johannes Schulz's description of "terra sigillata Silesiaca", he distinguished two types of clays; red and white. He defined these clays as gold that were changed to red clay due to the sun, "Axungia Solis", and white clay due to the moon, "Axungia Lunae" [8,9].

Montanus's descriptions focused mainly on therapeutic indications for the use of Strzegom clay. He observed its occurrence on three mountains within the Strzegom range: Breitenberg (Góra Szeroka), Georgenberg (Góra Świętojerska or Góra Bazaltowa), and Kreuzberg (Góra Krzyżowa) [8,18]. In 1580, Silesian clay was 
already known as a therapeutic agent for canine rabies in the Land of Hessen in West Germany [5], and by 1852 it could be purchased at markets in Frankfurt. In 1618, "terra Silesiaca” was first named in the "Pharmacopoeia Londinensis" alongside the classic clays of the Mediterranean region $[1,8]$. In 1589, the Strzegom municipality obtained the imperial privilege to extract clay from these three deposits, and seals with a representation of the three Strzegom hills were used to confirm its authenticity.

In 1685, the imperial order was introduced for the absolute sealing of clay obtained from other Silesian deposits located in Strzegom (Striegau), Złotoryja (Goldberg), Janowice Duże adjacent to Legnica (Groß Jänowitz), Legnica (Liegnitz), Sichów (Seichau), Jawor (Jauer), Dzierżoniów (Reichenbach), Brachów (Brechelwitz), and Masłów adjacent to Trzebnica (Massel) [5,1]. The following clays were known in Upper Silesia: red clay from Płużnica (Groß Pluschnitz) and white clay from the Olesno region (Rosenberg), i.e., from Boroszów, called "terra Nobarsovensis". This clay was discovered in 1700 by Gottfried Wahl, who came from Świebodzice (Freiburg) and was a councillor in Oleśnica (Oels). In 1714, Paul Jakob Marperger mentioned its antitoxic and antipyretic action, and it was also indicated for stomach disorders $[5,18]$.

From the $16^{\text {th }}$ to $18^{\text {th }}$ centuries, dishes were made from "terra sigillata Silesiaca". In the Masłów region during the $18^{\text {th }}$ century, pills were made from clay and used as a medicine, which was named Töppelberg, after the place where it was discovered; the hill of Töppelberg, located in the west. In the $18^{\text {th }}$ century, Silesian clay was still used as a medicine, and according to Brunner, its health benefits had been known since prehistoric times [1,5]. According to Marpergra's description, Strzegom clay was used for slowhealing wounds caused by bites. It was used externally in the form of compresses and poultices, as well as internally in the form of a liquid solution with water, wine, beer, and vinegar, or in the form of pills. A compress could also be made after mixing the clay with the saliva of an ill, fasted patient who had not eaten onions, garlic, or pork for a few days.

It was indicated for the treatment of wounds after being bitten by a dog infected with rabies. Other indications included intestinal disorders, bloating, constipation, eye disease, nosebleeds, wound bleeding, headaches, fever, and cholera. Indications for the therapeutic use of clay from the Silesian deposits were also described in "Rariora naturae \& artis, item in re medica; oder, Seltenheiten der Natur und Kunst des kundmannischen NaturalienCabinets, wie auch in der Artzeney-Wissenschafft" by a physician of the Hochberg family, Johann Kundmann. According to Kundmann, dishes made from "terra sigillata" clay extracted from the Silesian deposits had therapeutic properties in folk medicine; it was believed that anyone who drank from a clay dish every day would avoid food poisoning.

According to Kundmann's description in 1633, red clay from Płużnica adjacent to Strzelce Opolskie, "terra sigillata Magni
Plussnicensis", helped the local community as a preventive agent to control a cholera epidemic and mass cattle death in Upper Silesia. Andreas von Wehner, an aristocrat and councillor from Wrocław, was granted permission to extract therapeutic clay from Płużnica, which he sealed with a crescent and three arrows. In addition to external compresses, the clay was also mixed with wine or beer by the local population and consumed orally. For use in animals, the clay was mixed with vinegar and ash [6]. In Strzegom, the production of the drug was discontinued during the second half of the $18^{\text {th }}$ century. Today, collections of the clay pills originating from Strzegom and other regions of Lower Silesia are placed, among others, in the Museum in Wałbrzych, the Museum of Old Trading in Świdnica, the Mineralogical Museum of the University of Wrocław, and the Museum of Pharmacy in Heidelberg.

\section{Types of Medicinal Clays}

Based on research regarding medicinal clays and the scale of source materials, including marked seals on clay deposits, the following best known clays used in medicine can be determined: clay from Lemnos ("terra Lemnia", "terra sigillata"), clay from Malta ("terra Malitea"), clay from Palestine ("terra Hierosolymitanae"), clay from Armenia ("terra Armenica"), clay from Turkey ("terra Turcica"), clay from Silesia ("terra Silesiaca"), clay from Livonia ("terra Livonica"), Italian clay ("terra Florentina"), Portuguese clay ("terra Portugallica"), Spanish clay ("terra Hispanica"), and clays from Kisameet Bay in Canada, Côte d'Ivoire, Scandinavia, and Persia.

\section{Conclusion}

\section{Mechanism of Action and Scientific Evidence of Medicinal Clays Used in Traditional Therapy}

Although clays were used for medicinal purposes for millennia, they remained largely unexamined in terms of their mechanism of action and potential benefits in medicine. Recently, however, there has been an increased interest in the geochemical properties of these minerals with respect to antibacterial and anti-inflammatory action [21]. The emergence of antibiotic-resistant bacteria has accelerated the search for new sources of antibacterial compounds. Bacteria quickly gain resistance to antibiotics that target specific cellular mechanisms, DNA replication, and the synthesis of proteins and cell walls. As a result, scientists have become interested in ageold traditional mineral-based therapies against bacterial infections. The Kisameet clay solution used for centuries by the Heiltsuk Indian tribe (now in British Columbia, Canada) has proven its effectiveness against 16 strains of multidrug-resistant nosocomial infection-causing bacteria including Enterococcus faecium, Staphylococcus aureus, Klebsiella pneumoniae, Acinetobacter baumannii, Pseudomonas aeruginosa, and Enterobacter sp.

The results suggest that clay may be used as a therapeutic option to treat serious infections caused by these bacteria. Studies by Williams and Haydel [2] suggest that clay minerals used by AfroAmericans to treat Buruli ulcer, known as "flesh eating bacteria", 
speed up the process of wound healing in persons infected with bacillus Mycobacterium ulcerans. Morrison et al. [21] proved that certain clays kill antibiotic- resistant bacteria, including methicillinresistant Staphylococcus aureus. Oregon blue clay has shown strong anti-bacterial action, containing soluble reduced metals and clay minerals that absorb cations, which ensure prolonged metal release and the production of toxic hydroxyl radicals.

Efimenko et al. [22] described the anti-inflammatory action of clay from Tambukan lake in Russia. For clays used to treat chronic slow-healing wounds, $\mathrm{pH}$ and Eh (redox potential) buffering mechanisms seem to be crucial for the curative capacity as an alternative to antibiotics in medicine. Silesian healing clay was used as one of the first in Europe, in medicinal mixtures used by herbalists from Krummhübel in the Sudety Mountains $\left(17^{\text {th }}\right.$ to $19^{\text {th }}$ century), Silesia [23,24]. Currently, in 2017-2018, two historic healing clay "terra sigillata Silesiaca" deposits have been confirmed in Silesia, which, after previous research, may be used in natural medicine. They are: Boroszów and Płużnica (Figure 2).

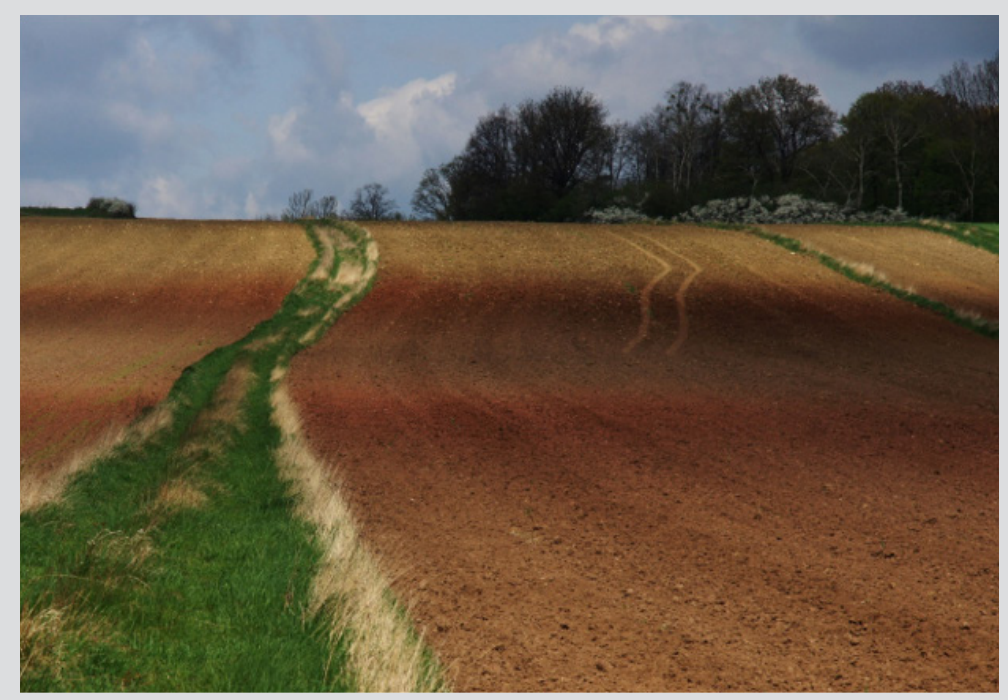

Figure 2: Decks of preserved historic medicinal clays in Płużnica, Silesia (Photo by K. Spałek).

\section{References}

1. Dannenfeld KH (1984) The introduction of a new sixteen-century drug: terra Silesiaca. Med Hist 28(2): 114-118.

2. Williams LB, Haydel SE (2010) Evaluation of the medicinal use of clay minerals as antibacterial agents. Int Geol Rev 52(7/8): 745-770.

3. Sousa Figueiredo Gomes C (2008) Naturotherapies Based on Minerals. Geomaterials 3(1): 1-14.

4. Ferrell RE (2008) Medicinal clay and spiritual healing. Clays Clay Miner 56(6): 751-760.

5. Brunner K (1911) Schlesische Terra sigillata. Zeitschrift des Vereins für Volkskd Berlin 21: 345-351.

6. Kundmann JC (1737) Rariora naturae \& artis, item in re medica; oder Seltenheiten der Natur und Kunst des kundmannischen NaturalienCabinets, wie auch in der Artzeney-Wissenschafft. Breslau.

7. Carretero MI (2002) Clay minerals and their beneficial effects upon human health. A review. Appl Clay Sci 21(3-4): 155-163.

8. Macgregor A (2013) Medicinal terra sigillata: a historical, geographical and typological review. In: Duffin CJ, Moody RTJ, Gardner Thorpe C (Eds.), A Hist Geol Med pp. 124-127.

9. Duffin CJ (2017) Fish, fossil and fake: medicinal unicorn horn. In: Duffin CJ, Gardner Thorpe C, Moody RT (Eds.), Geol Med Hist Connect. London pp. 236.

10. Schwenckfeld C (1600) Stirpium \& Fossilium Silesiae Catalogus. Görlitz.

11. Czubala D (1984) O ludowym leczeniu gliną w Polsce. Na podstawie badań przeprowadzonych w Polsce wśród garncarzy. Lud 68: 181-195.
12. Williams LB, Holland M, Eberl DD, Brunet T, Brunet de Courrsou L (2004) Killer clays! Natural antibacterial clay minerals. Mineral Soc Bull 139: 3-8.

13. Sánchez Espejo R, Aguzzi C, Cerezo P, Salcedo I, López Galindo A, et al. (2014) Folk pharmaceutical formulations in western Mediterranean: identification and safety of clays used in pelotherapy. J Ethnopharmacol 155(1): 810-814.

14. Adusumilli S, Haydel SE (2016) In vitro antibacterial activity and in vivo efficacy of hydrated clays on Mycobacterium ulcerans growth. BMC Complement Altern Med 16: 40.

15. Sousa Figueiredo Gomes C (2017) Healing and edible clays: a review of basic concepts, benefits and risks. Environ Geochem Health 40(5): 17391765 .

16. Hosseinkhani A, Montaseri H, Hosamo A, Zarshenas MM (2016) An evidence-based review on medicinal value of clays in traditional Persian medicine. Curr Drug Discov Technol 14(1): 2-7.

17. Kneipp S (1894) Mein Testament für Gesunde und Kranke. Kempten: Kösel Verlag.

18. Volkmann GA (1720) Silesia subterranea, oder Schlesien. Mit seinen unterirrdischen Schatzen, Seltsamheiten welche dieses Land mit andern gemein oder zuvoraus hat als Edelen, und Unedelen, ohne und mit Figuren sich praesentirenden und seltsam gebildeten Steinen. Leipzig: MG Weidmann.

19. Behroozian S, Svensson SL, Davies J (2016) Kisameet clay exhibits potent antibacterial activity against the ESKAPE pathogens. MBio 7: e01842-15.

20. Svensson SL, Behroozian S, Xu W, Surette MG, Li L, et al. (2017) Kisameet glacial clay: an unexpected source of bacterial diversity. MBio 8: e0059017. 
21. Morrison KD, Misra R, Williams LB (2016) Unearthing the Antibacterial Mechanism of Medicinal Clay: A Geochemical Approach to Combating Antibiotic Resistance. Sci Rep 6: 19043.

22. Efimenko NV, Abramtsova AV, Kaisinova AS (2016) The investigation of immunological effects of the new balneotherapeutic preparation glinofir used for the treatment of adjuvant arthritis. Vopr Kurortol Fizioter Lech Fiz Kult 93(4): 56-59.

ISSN: 2574-1241

DOI: 10.26717/BJSTR.2019.20.003457

Krzysztof Spałek. Biomed J Sci \& Tech Res

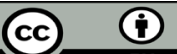

This work is licensed under Creative Commons Attribution 4.0 License

Submission Link: https://biomedres.us/submit-manuscript.php
23. Morrison KD, Underwood JC, Metge DW, Eberl DD, Williams LB (2014) Mineralogical variables that control the antibacterial effectiveness of a natural clay deposit. Environ Geochem Health 36(4): 613-631.

24.Spałek K, Spielvogel I, Proćków M, Proćków J (2019) Historical ethnopharmacology of the herbalists from Krummhübel in the Sudety Mountains (seventeenth to nineteenth century), Silesia. J of Ethnobiology and Ethnomedicine 15(1): 24.

$\begin{array}{ll}\text { BIOMEDICAL } & \text { Assets of Publishing with us } \\ \text { RESEARCHES } & \text { - Global archiving of articles } \\ & \text { - Immediate, unrestricted online access } \\ & \text { - Rigorous Peer Review Process } \\ \end{array}$

